\title{
THE INFLUENCE OF NATURAL CLIMATIC FACTORS ON THE GEOMECHANICAL PROPERTIES OF SILICEOUS LIMESTONES FROM KAZIMIERZ DOLNY (POLAND)
}

\author{
Joanna Pinińska, Alicja Bobrowska, Dominik Lukasiak \\ Department of Geology, University of Warsaw, ul. Żwirki and Wigury 93, 02-089 Warsaw, Poland, \\ e-mails: joanna.pininska@uw.edu.pl; a.bobrowska@uw.edu.pl; dominik.lukasiak@uw.edu.pl
}

\begin{abstract}
Based on the example opoka, stone architecture of Kazimierz Dolny, modern research methods were applied to an analysis of geomechanical qualities of this special rock, selected very efficiently by medieval, local builders. Owing to theirs skill and the qualities of the chosen material, fortifications, religious and residential buildings have been preserved in good condition to the present day. It was analysed what factors of the opoka aging are the most responsible for their destruction resistance in the long time scale. The results of studies indicate that opokas have an increased ability to reduce the uniaxial compression strength due to the impact of cycling freezing and thermal shock. This observation shows that opokas are characterized by a high resistance to humidity.
\end{abstract}

Key words: opoka, Kazimierz Dolny, climatic factors, geomechanics, deterioration.

Manuscript received 10 May 2016, accepted 18 November 2016

\section{INTRODUCTION}

The valley of central Vistula is a special area of Poland, where a well-known water trade route from southern Europe to the Baltic Sea made a significant impact on economic development of the region and farther on a unique style of the Middle Ages stone architecture. Common Upper Cretaceous and Neogene carbonate rocks from easily accessible, exposed slopes of the river, has had positive impact on the buil ding industry prosperity. Following the development of the mining of siliceous limestone rocks opoka: a porous, flinty, and calcareous sedimentary rock, consisting of fine-grained opaline silica (up to $90 \%$ ), and hardened by the presence of silica of organic origin (silicified residues of radiolarian, sponge spicules, and diatoms), commonly known as a "white stone", urban complexes were formed with a characteristic architecture, exerting considerable impact on the cultural landscape of the region. The evidence of this influence is to this day preserved in medieval character of the urban layout of Kazimierz Dolny and its stone architecture, changed in $16^{\text {th }}$ century from the wooden and inflammable to brick one (Fig. 1).

Despite the fluctuation of its economic development and war devastation, Kazimierz Dolny is contemporarily an urban and landscape complex in which the historic system of a trading granary located on the route of the Vistula has been preserved. This complex was declared as a monument of history in 1994 by decree of the President of the Republic of Poland, Lech Walesa.
The origins of the settlement date back to the $11^{\text {th }}$ century. They were initially associated with the Order of the Benedictines and afterwards the Order of the Norbertines, which gave the settlement the name of Kazimierz, recorded for the first time in 1249. The founding of the city and the construction of a fortified castle is attributed to the Polish King Kazimierz III the Great. In the first half of the $14^{\text {th }}$ century, the Polish King Wladyslaw Lokietek founded in the city a parish church and awarded city rights. A market and streets and plots of land for residential construction were demarcated. Kazimierz Dolny flourished in the $16^{\text {th }}$ century, when the grain trade with grain floated by the Vistula to Gdansk developed and, after numerous fires, wooden buildings were replaced with brick architecture. In this period lavishly decorated granaries, town houses and religious buildings were built. In the history of medieval stone building the strongest footprint was made by Upper Cretaceous opoka, exploited directly within the area of the city of Kazimierz Dolny, and also in nearby Piotrawin, Nasilow, Janowiec or Bochotnica. Situated in vicinity, accessible, easy for treatment, the rock allowed for extremely varied decoration of facades with an individual character proving the craftsmanship and high aspirations of the then masters of construction ( Fig. 2).

\section{GEOMECHANICAL QUALITIES OF ROCKS}

Although the knowledge about the beneficial building properties of the opoka rocks has deep historical background, the modern geomechanical studies help establish the 

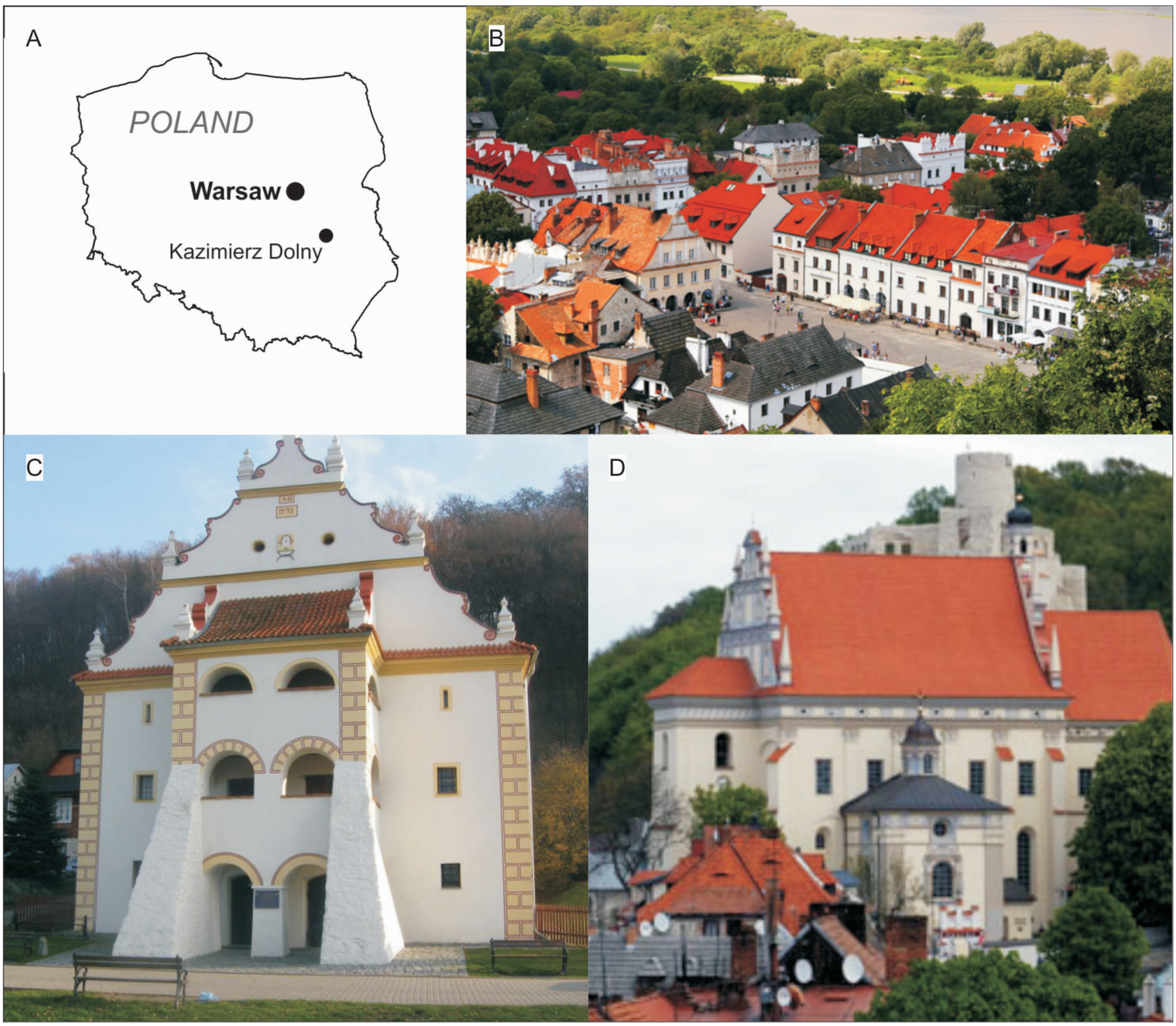

Fig. 1. Kazimierz Dolny. A - location; B - a preserved medieval urban layout of the old town; C, D - examples of medieval brick buildings with masonry (in order: a granary, a parish church).

origins of the unusual durability of such a weak, according to a standard classification of durability, construction material (Pinińska and Dziedzic, 2006; Pinińska, 2009, 2010; Marini and Bellopede, 2012; Bellopede et al., 2005; Bobrowska, 2013; Pinińska et al., 2014; Bobrowska and Domonik, 2015). Researches are based on complex laboratory testing on the samples of opoka rocks from Kazimierz Dolny. Petrographic analyses, ultrasound and physical-mechanical tests were carried out together with acoustic emission during the rock fracture under load. The profile of damaged surface was made by means of the roughness test with usage of HommelWerke Profilometer. In the mechanical tests the methodology recommended by the ISRM (1988) was applied and the behaviour of the rocks in pre-critical and postcritical states of damage against the background of acoustic emission (AE) was analysed. The siliceous limestone (opoka) rocks which show the natural block fragmentation in the quarry (Fig. 3A ) belong to the very light and light rocks ( $\rho_{\mathrm{s}}$ of $1.4 \mathrm{~g} / \mathrm{cm}^{3}$ to $\left.1.6 \mathrm{~g} / \mathrm{cm}^{3}\right)$, are highly porous $(\mathrm{n} \sim 40 \%$ ) with the strength in the range of 10-30 MPa. It classifies them according to PN-84/B-01080 to the rocks of low and medium durability. However the micrite semiopaque crystalline matrix of limestone with large amounts of siliceous sponge spiculas and residuas of radiolarian, creates a skeletal structure, easily observed in the microscope image (Fig. 3B). Thanks to this grillage reinforcement, the opokas are resistant to cracking and, comparing to other local carbonate raw materials of similar density, are relatively durable (Fig. 3C). Along with seasoning opokas harden. Their strength increases with time. This advantageous feature of opoka was known and used in the Middle Ages. Laboratory testing of W.C. Kowalski (1961), W.C. Kowalski and Łozińska-Stępień (1965) show that after several months of seasoning the strength of opoka increases more than $60 \%$ (Fig. 3D).

At the same time their high porosity creates their excellent insulation and lightweight makes their shaping easy. The process of strengthening of rock caused by siliceous reinforcement of structure is confirmed by studies of the defor- 


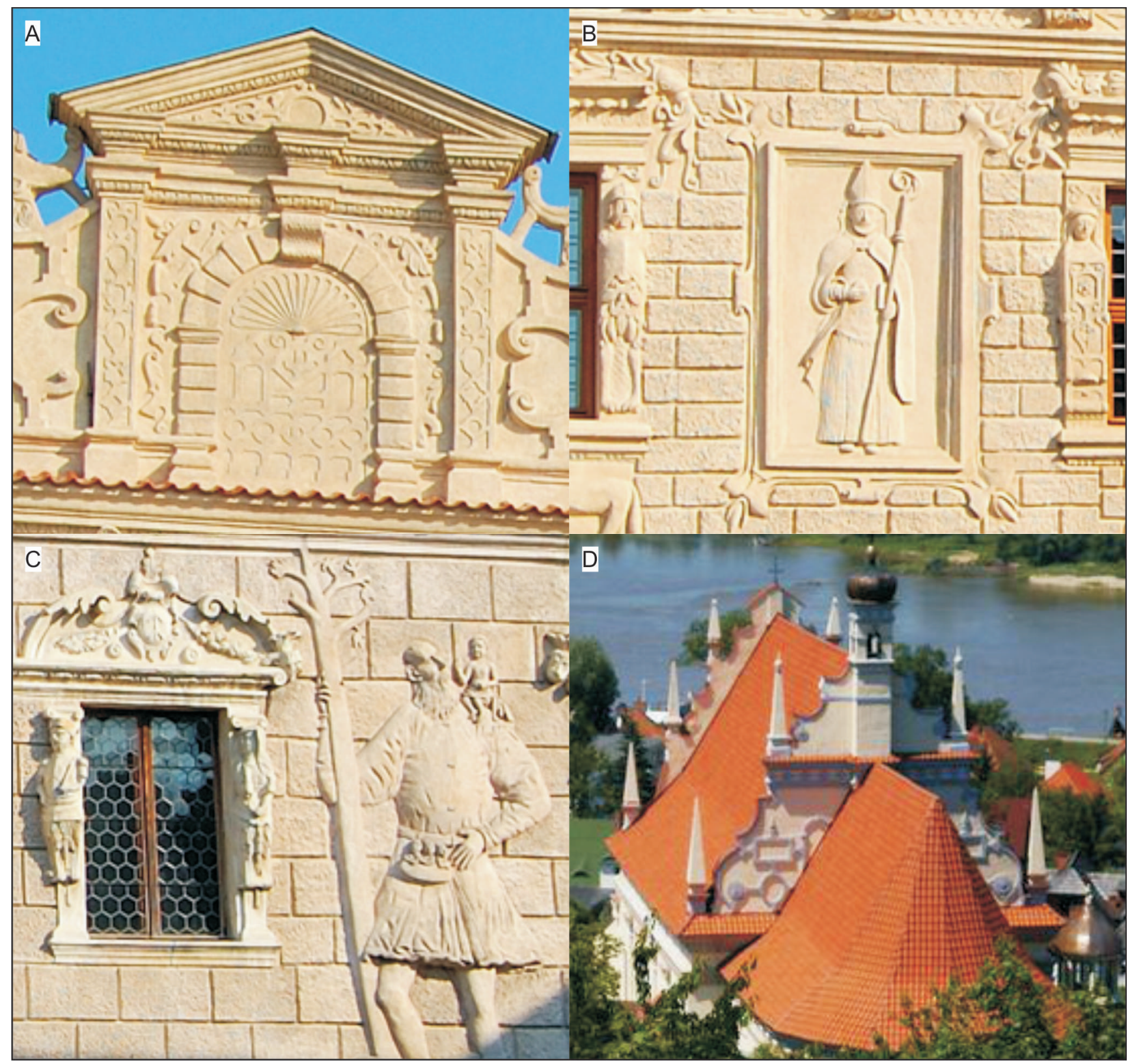

Fig. 2. A, B, C - Ornamental facades of Przybyla brothers' town houses at St. Christopher Street (ca.1615); D - church of St. John the Baptist (1586-1589).

mation path (Fig. 4A) and parallel acoustic emission path (Fig. 4B) while loading. As can be seen from the test graphs at the pre-critical state of deformation only a few signs of brittle destruction can be observed and the same is recorded by a very poor pre-critical acoustic emission activity.

In the post-critical state, after the destruction path passes the pick point $\left(\mathrm{R}_{\mathrm{c}}\right)$, opokas still retain a significant residual strength $\left(\mathrm{R}_{\text {crez }}\right)$ of up to $50 \% \mathrm{R}_{\mathrm{c}}$. This is connected with the appearance of multiple small micro-cracks that are readable on both deformation and acoustic emission curves. They may become paths for water into the porous structure. On the other hand, the test results of the roughness shown by the HommelWerke Basic Map, prove that the cracks have a high surface roughness. Thanks to this opokas still keep the residual strength despite of their significant deformation (Fig. 5).

\section{THE SUSCEPTIBILITY OF OPOKAS TO DEFORMATION}

The results of observation of the opokas in the historic buildings of Kazimierz Dolny lead to the conclusion, that the most common mechanisms of deterioration of their stone walls due to the aging processes are: change of wall tint, loss of wall bricks and their mortar (Fig. 6).

The damages of the opoka walls of the monuments are related to the penetration of corrosive water solutions into the cracked blocks and the invasion of microorganisms, both changing the colour of the stone and causing crushing and loss of mortar during the seasonal climatic changes. Lack of proper drainage and location near the steep slopes causes instability of their foundation and cracking of stone walls. Ad- 

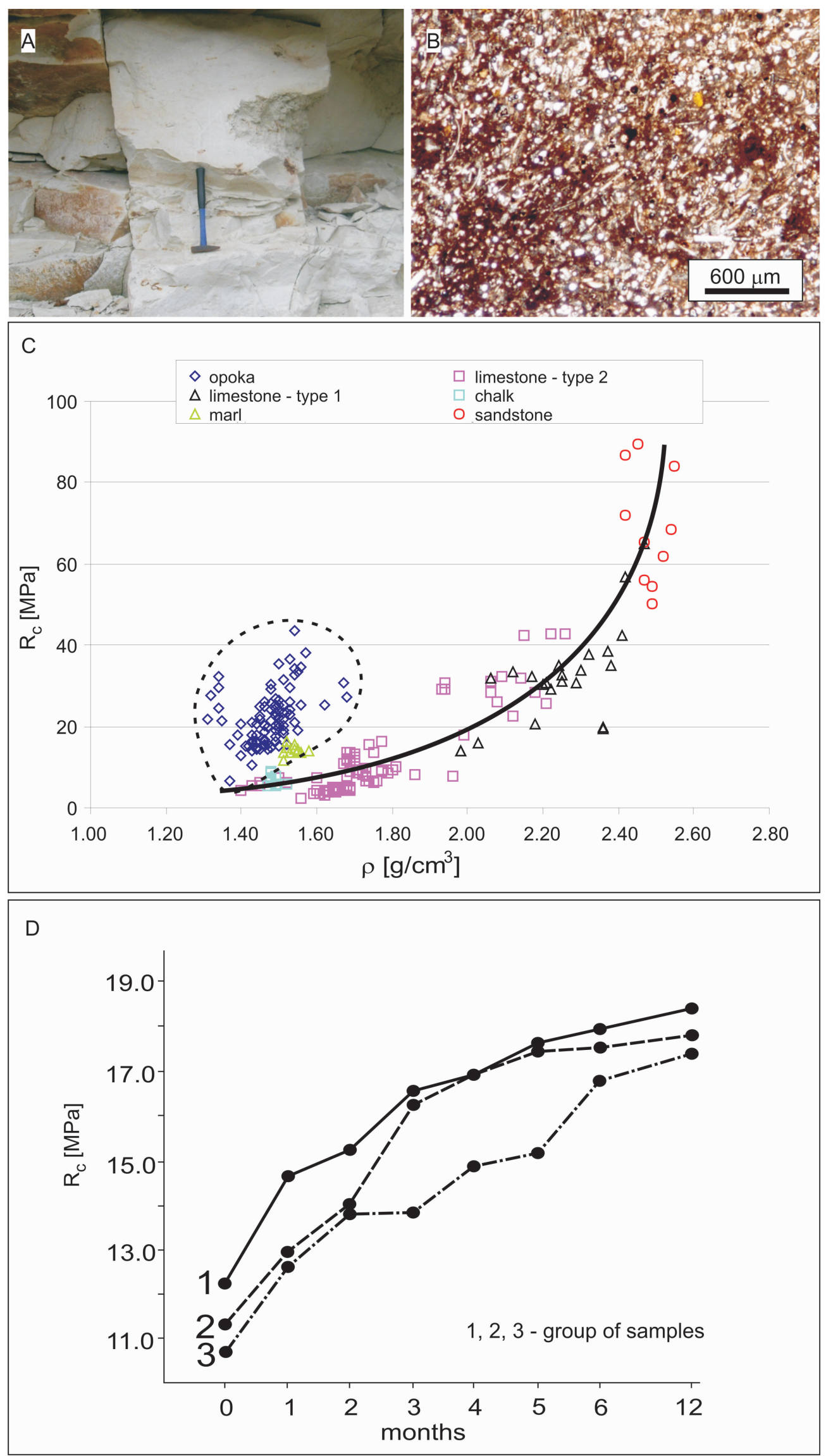

Fig. 3. The advantageous properties of opokas. $\mathbf{A}$ - block fragmentation; $\mathbf{B}$ - the micrite structure reinforced by the grillage of silica sponges spicula; $\mathbf{C}$ - a low density $\left(\rho_{\mathrm{s}}\right)$ rock with a relatively high compression strength $\left(\mathrm{R}_{\mathrm{c}}\right)$; $\mathbf{D}-$ a rock becoming harder (increase of $\left.\mathrm{R}_{\mathrm{c}}\right)$ due to seasoning (Kowalski, 1961). 


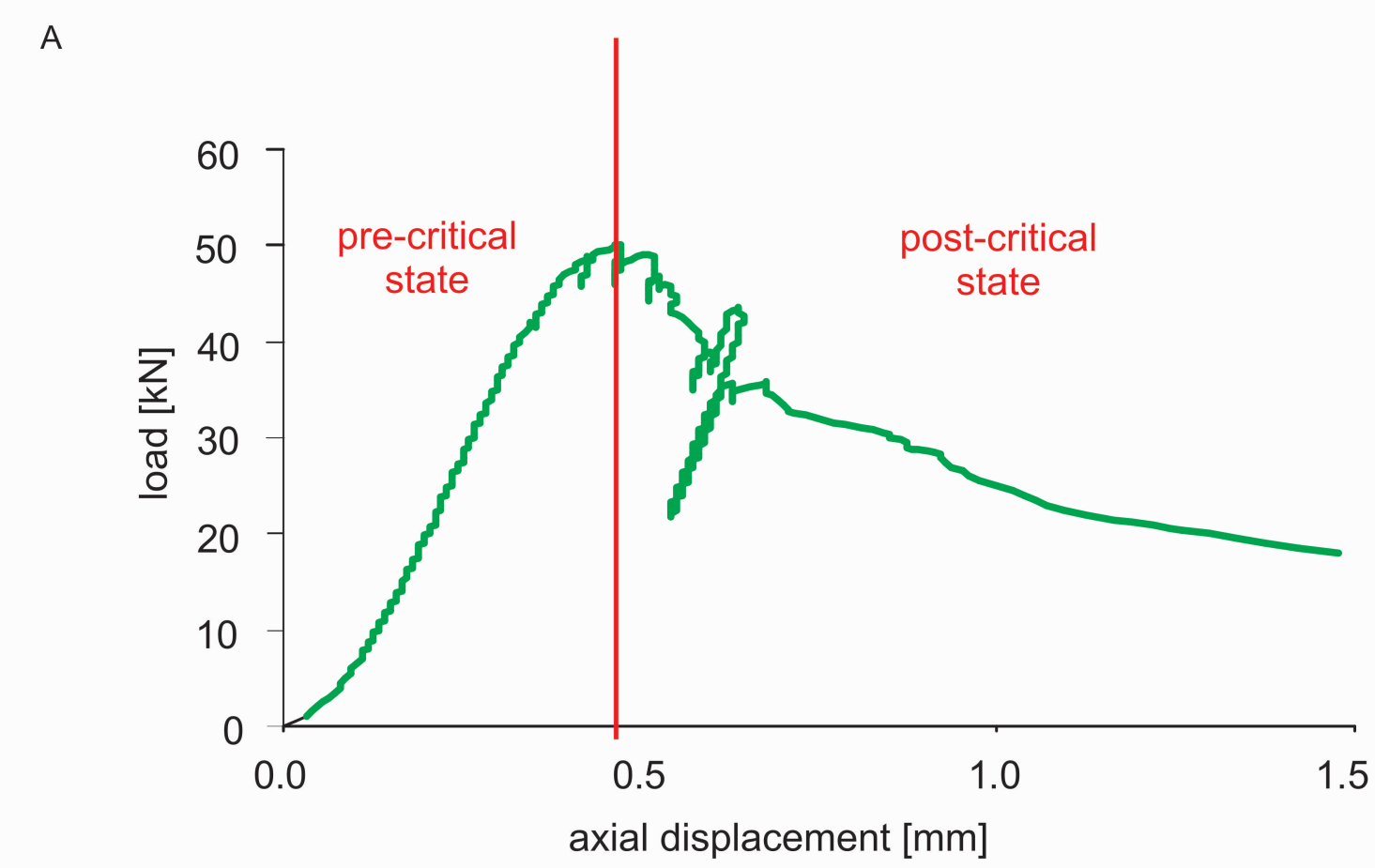

B

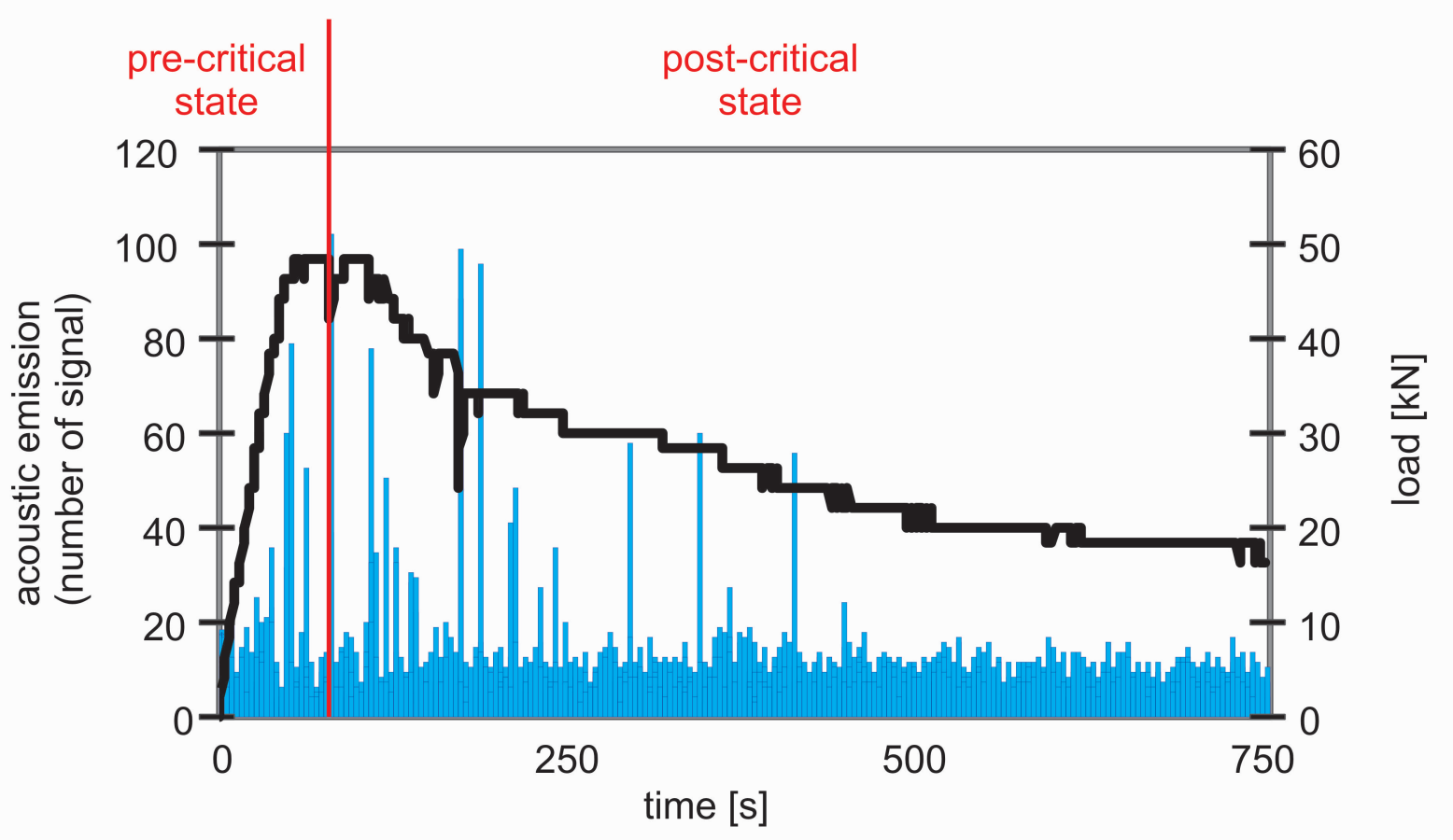

acoustic emission

T. load [kN]

Fig. 4. Pre-critical and post-critical paths of deformation of opokas: $\mathbf{A}$ - the deformation curve; $\mathbf{B}$ - the acoustic emission curve.

ditionally, the historic buildings of Kazimierz Dolny are often poorly maintained by usage of mortars not proper to the opoka features. The walls preserved by cover of plaster lose their regional character so important for medieval heritage. Due to the observed damaging of the historical walls, the opokas properties were analysed by modelling the interactions between the natural environment and opoka behaviour at laboratory. As a main impact aging factor in the environmental conditions of Kazimierz Dolny was chosen a variable continental climate, with high rain prevailing at summertime 


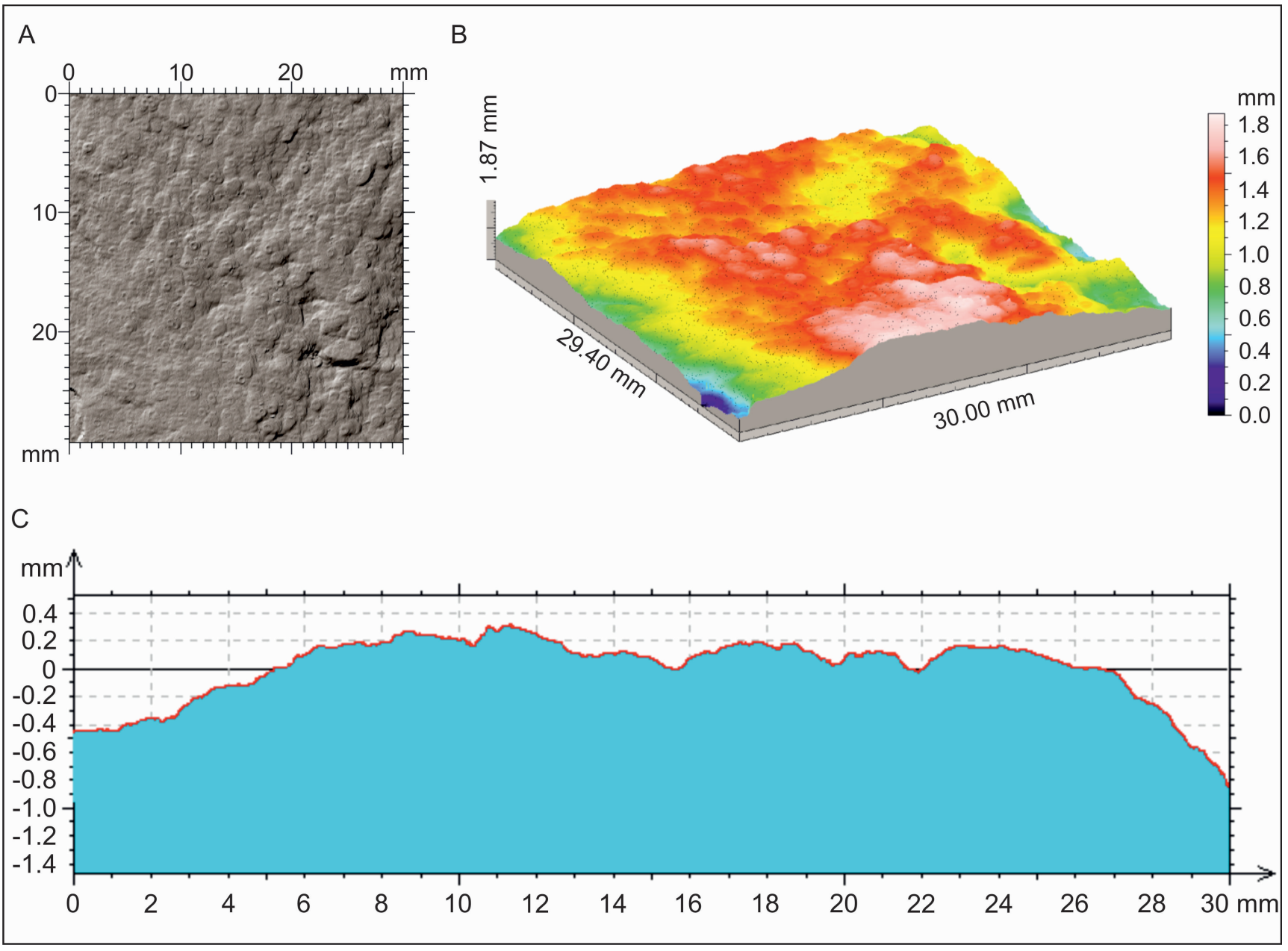

Fig. 5. Roughness surfaces of the cracks in opoka: $\mathbf{A}$ - diagram 2D of the crack; $\mathbf{B}$ - diagram $3 \mathrm{D}$ of the crack; $\mathbf{C}$ - roughness profile (Pinińska and Dziedzic, 2006; 2007).

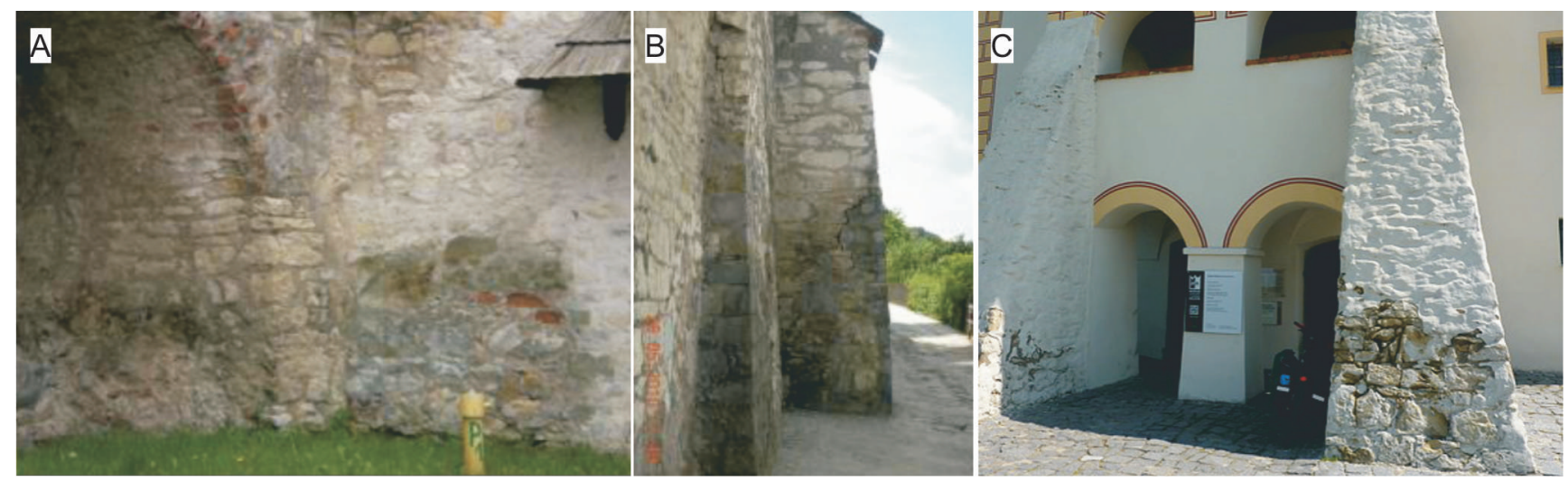

Fig. 6. Humid and discoloured parts of a walls: $\mathbf{A}$ - the castle stone walls, $\mathbf{B}$ - displacement of the walls on the steep slopes, $\mathbf{C}-$ opokas walls of a former granary covered with plaster.

(average annual rainfall $550 \mathrm{~mm}$ ) with a significant summer insolation of white walls (at temperatures up to $50^{\circ} \mathrm{C}$ ) at an average temperature of $-5.0-18.7^{\circ} \mathrm{C}$ (Woś, 1999).

The 20 samples of opoka were subjected to cyclic testing of freezing and thawing resistance (PN-EN 12371 ), thermal shock resistance (PN-EN 14066), deterioration of water absorption (PN-EN 13755) and the compression strength tests (PN-EN 1926) at initial state and after model tests. This way, the deterioration index of integrity (I) was established, characterized by a reduction of the initial compressive strength $\left(\mathrm{R}_{\mathrm{c}}\right)$ of rocks due to the influence of a given destructive factor. It was expressed by the relation of the initial value $\left(R_{c}\right)$ to the value after the modelling $\left(\mathrm{R}_{\mathrm{cx}}\right)$. Studies indicate that opokas strength under the influence of the humidity decrease by nearly $10 \%$ and due to the impact of cyclic freezing and thawing and thermal shock resistance of about $29 \%$ (Table 1 ). 

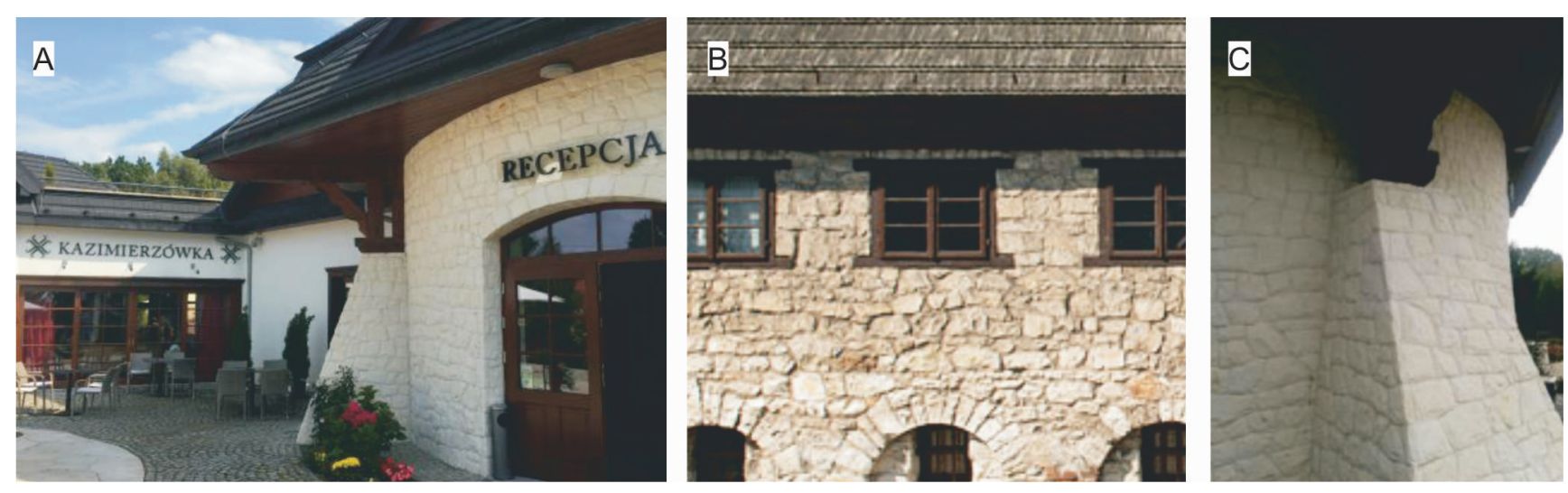

Fig. 7. A - Fragments of a modern hotel in Kazimierz Dolny; $\mathbf{B}$ - a renewed synagogue; $\mathbf{C}-$ a stylish retaining wall protected from rain and moisture.

Table 1

Average values of uniaxial compression strength $\left(\mathrm{R}_{\mathrm{c}}\right)$ and index of integrity (I) of opokas of Kazimierz Dolny in modelled conditions

\begin{tabular}{|l|c|c|}
\hline \multicolumn{1}{|c|}{ Test condition } & $\begin{array}{c}\text { Uniaxial compressive } \\
\text { strength }[\mathrm{MPa}]\end{array}$ & $\begin{array}{c}\text { Index Integrity } \\
\mathrm{I}=\mathrm{R}_{\mathrm{cx}} / \mathrm{R}_{\mathrm{c}}[-]\end{array}$ \\
\hline initial state $\mathrm{R}_{\mathrm{c}}$ & 26.0 & \\
\hline freezing and thawing $\left(\mathrm{R}_{\mathrm{cm}}\right)$ & 18.4 & 0.50 \\
\hline thermal shock $\left(\mathrm{R}_{\mathrm{cst}}\right)$ & 18.0 & 0.48 \\
\hline water absorption $\left(\mathrm{R}_{\mathrm{cn}}\right)$ & 23.2 & 0.80 \\
\hline
\end{tabular}

These studies shows that opokas are characterized by a high resistance to humidity.

\section{SUMMARY}

The results of contemporary geomechanical studies fully confirm the specific properties of opoka and explain their widespread use in the medieval local stone architecture and development of medieval building industry. Basing on the opokas mining the monumental, $16^{\text {th }}$ century stone architecture of Kazimierz Dolny raised thanks to the knowledge and skill of masters of constructions of that time, and currently occupies an important place in the cultural heritage of the south-eastern Poland. However the results of the geomechanical researches show that opokas, without proper conservation are sensitive for cyclic climate changes and aging and the subgrade of the foundation of structure needs to be well drained.

In modern time the new technologies and the development of global distribution of decorative stones superseded the medieval prevalence of opokas in the regional construction industry. However, the former splendour of Kazimierz Dolny is being restored in a modern form. In old medieval granaries, hotels are being set up, the reconstruction of the fortified castle with the use opoka wall is quickly progressing, and in local, stylish buildings, outskirts of the old town the opoka starts to dominate (Fig. 7).

This trend supports the tradition and decorative values of "white stone". It emphasizes the local nature of the availability of the material and exposes its special properties. It is crucial to remember, however, that the use of rocks requires the seasoning opoka after extraction from the quarry and its protection from humidity in masonry structures. In the varied morphology of Kazimierz Dolny a proper positioning and use of reinforcements and retaining walls, in accordance to the medieval art, is of a vital importance. Thus constructors should remember that cracking and loss of brick mortar is result of the movement of the subgrade over the steep slopes and causes the circulation of corrosive solutions through the rock. Consequently the rock with destructed structure becomes more sensitive to climatic corrosion and anthropic pressure.

\section{REFERENCES}

Bellopede, R., De Regibus, C., Manfredotti, L., Marini, P. 2005. Water Absorption and ultrasound pulse velocity to evaluate the decay of stones, in Non Destructive Investigations and Microanalysis for the Diagnostics and Conservation of the Cultural and Environmental Heritage, 15-19, Maggio Lecce

Bobrowska, A. 2013. Changes in the strength of salt crystallization conditions and the effect of sulphur dioxide on some macroporous carbonate rocks. Przegląd Geologiczny, Vol. 61, No. 5, 311-314 (in Polish with English summary).

Bobrowska, A., Domonik, A. 2015. Ultrasonic waves and strength reduction indexes for the assessment of the advancement of deterioration processes in travertines from Pamukkale and Hierapolis (Turkey). Studia Geotechnica et Mechanica, Vol. 37, No.3, 3-9.

ICOMOS, 2010. International Scientific Committee for Stone (ISCS), Illustrated glossary on stone deterioration patterns.

ISRM, 1988. Suggested Methods for Determinig the Fracture Toughness of Rock. Commission on Testing Methods.

Kowalski, W.C. 1961. The compressive strength Senonian construction rocks in the rearch area of the Middle Vistula river on the background of their lithology. (Wytrzymałość na ściskanie budowlanych skał senońskich przełomowego odcinka Wisły środkowej na tle ich litologii), Biul. Geol., Wydz. Geol. UW., Vol. 1, Part 2. Warszawa (in Polish with English summary).

Kowalski, W.C., Łozińska-Stępień, H., 1965. Lithology of the Upper Cretaceous rocks of the Middle Vistula river valley and the adjacent uplands. Mat. Sympozjum w Kazimierzu Dolnym, NOT. Katowice, 805-819 (in Polish with English summary).

Marini, P., Bellopede, R. 2012. Sandstone decay: from historical buildings to laboratory tests, Structural analysis of historical constructions, 691-696.

Pinińska, J., Domonik, A., Dziedzic, A., Łukasiak, D. 2014. The 
methodology of a complex engineering-geological approach to establish a geopark: Case study of the Małopolska Wisła River Gorge. Geological Quarterly, 59 (2), 408-418.

Pinińska, J., Dziedzic, A., 2006. The strength and deformation properties of rocks. Part V Lublin region. Catalogue. (Właściwości wytrzymałościowe i odkształceniowe skał. Cz.V. Region lubelski. Katalog), Vol.9, Warszawa (in Polish).

Pinińska, J., Dziedzic, A., 2007. Resistance and deformation rock properties. Part V Lublin region. Descriptions and interpretation. (Właściwości wytrzymałościowe i odkształceniowe skał. Cz.V. Region lubelski. Objaśnienia i interpretacja), Vol.10, Warszawa (in Polish).

Pinińska, J. 2008. The Lublin Siliceous Carbonate Rocks - a Medieval Building Material, its Geological Setting, Specific Properties and Deterioration Processes. 11 ${ }^{\text {th }}$ International Congress on Deterioration and Conservation of Stone. Vol. 1. Nicolaus Copernicus University press. Toruń. Poland,
$725-732$.

Pinińska, J. 2010. Rock mining industry in the Lublin region. Destruction or Development. Prace i Studia Geograficzne. Vol. 44, Warszawa, 153-167 (in Polish with English summary).

PN-EN 12371. Natural stone test methods - Determination of frost resistance;

PN-EN 13755. Natural stone test methods - Determination of water absorption at atmospheric pressure;

PN-EN 14066. Natural stone test methods - Determination of thermal shock resistance;

PN-EN 1926. Natural stone test methods - Determination of compressive strength;

PN-84/B-01080. Kamień dla Budownictwa i drogownictwa. Podział i zastosowanie wg właściwości fizyczno-mechanicznych. PKN i M. Warszawa.

Woś, A., 1999. The Climate of Poland (Klimat Polski), PWN (in Polish). 